\title{
Ehlers-Danlos Sendromlu Kedi ve Köpeklerde D Vitamini Düzeyleri: Nutrisyonel Bozukluk Hipotezine Dair Olgu Serisi
}

\author{
Hasan ERDOĞAN ${ }^{*}$, Kerem URAL ${ }^{1}$, Pelin KANDEMİR ${ }^{1}$, Deniz Sude ATEŞ1 \\ 1 Adnan Menderes Üniversitesi, Veteriner Fakültesi, $\dot{I}_{c}$ Hastallklar Anabilim Dal, Aydm/TÜRKIYYE \\ *Corresponding author e-mail: hasan.erdogan@adu.edu.tr
}

ÖZ

Farklı hayvan türlerinde bildirilen ve derinin elastikiyetinde azalma, deride aşırı uzama, yumuşama bulgular gösteren Ehlers Danlos Sendromu (EDS) nadir görülen kalıtsal kollojen hastalı̆̆ıdır. Hayvanlarda dermatosparaksis ve kutanöz astenia olarak da bilinen bu hastalığın tanısı klasik klinik bulgular, cilt uzayabilirlik indeksi ile histopatolojide kalın, düzensiz ayrılıış kollojen demetlerinin görülmesine dayanmaktadır. Farklı yaş ( $\mathrm{n}=4$ kedi; 1-3 yaşlı ile $\mathrm{n}=6$ köpek 1-5 yaşlı), her 2 cinsiyetten kedi (2 erkek, 2 dişi) ve köpeğin (4 erkek, 2 dişi) dahil edildiği olgu serisinde serum $25(\mathrm{OH})$ D3 seviyeleri ile ilisskileri sunulmaktadır. EDS tanısı konulan kedi ve köpeklerde bulunan düşük vitamin D seviyeleri (toplamda 8/10) düşünüldügünde EDS' li kedi ve köpeklerde diğer beslenme eksikliklerinin yanı sıra vitamin D yetersizliğinin de göz önüne alınması gerektiği ve beşeri hekimlikte olduğu gibi oral vitamin D takviyesinin güvenle verilebileceği önerilmektedir.

Anahtar Kelimeler: Ehlers-Danlos Sendromu, kedi, köpek, vitamin D

\section{Vitamin D Levels in Cat and Dogs With Ehlers-Danlos Syndrome: Case Series Touching Nutritional Deficiency Hypothesis}

\begin{abstract}
Ehlers Danlos syndrome (EDS) reported varied animal species is a rare hereditary collagen disorder standing out reduced strength of skin being hyperextensible, velvety and fragile. Diagnosis of also termed dermatosparaxis or cutaneous asthenia in animals is based on classic clinical symptoms, skin extensibility index with histopathologic examination included thin, unregular seperated collagen bundles. In the presented case series enrolled different ages (1-3 years old 4 cats; and 1-5 years old 6 dogs) with both gender cats (2 males, 2 females) and dogs (4 males, 2 females) has been conferred serum $25(\mathrm{OH})$ D3 levels associations. Just as dog and cats diagnosed with EDS found lower vitamin D levels (total 8 of 10) are considered, it has recommended in cat and dogs with EDS taking into account of vitamin D deficiency as well as some other nutritional deficiencies and giving oral vitamin $\mathrm{D}$ supplements with safety as human medicine.
\end{abstract}

Keywords: Ehlers-Danlos Syndrome, cat, dog, vitamin D 


\section{GİRIŞ}

Bir grup kalitsal bağ dokusu hastallğı olan Ehlers Danlos sendromu (EDS), insanlarda olduğu kadar hayvanlarda da bilinmektedir (Pyeritz, 2012). Bu hastalığın doğal olarak ortaya çıkan formu atlar (De Paepe ve Malfait 2012, Beighton ve ark. 1998, Beighton ve ark. 1986), kediler (Germain 2007, De Felice ve ark. 2004, Lum ve ark. 2011, Oderich ve ark. 2005, Pepin ve ark. 2000), köpekler (Bergqvist ve ark. 2013, Busch ve ark. 2014, Horowitz ve ark. 2000, Malfait ve De Paepe 2009), buzağllar, koyunlar ve tavşanlar (De Paepe ve Malfait 2012, Malfait ve De Paepe 2009) olmak üzere farklı hayvan türlerinde bildirilmektedir. Bununla birlikte hastalık kedilerde nadiren görülür ve mevcut raporların çoğu bireysel vakaların tanımlarıdır (Beighton ve ark. 1998). Etkilenen hayvanlar hiperekstensibilite ve kirlgan bir cilde sahiptir (Pyeritz 2012, Oderich ve ark. 2005). Gecikmiş yara iyileşmesinin klinik ve histolojik kriterler kullanılarak insanlarda EDS'nin bir komplikasyonu olduğu, köpeklerde ve kedilerde yara iyileşmesinin EDS'ye ilişkin olduğu bildirilmiştir (Asherson ve ark. 2006). $\mathrm{Bu}$ bozukluklara hayvanlarda dermatosparaksis veya kutanöz asteni de denilmektedir (Pyeritz. 2012).

Tanı, histopatolojik incelemelerle doğrulanır, birbirinden uzak bir mesafede yer alan ve daha küçük parçalara ayrilan ve düzensiz bir model oluşturan kolajen liflerinin anormal yapısını açığa çıkarır (Calatzis ve ark. 2003). Rutin boyama tekniğinden ayrı olarak, bağ dokusunun yapılarını seçici bir şekilde ortaya koyan birkaç yardımcı yöntem vardır. Teşhis prosedüründe yararlı bir araçtır. Van Gieson, Mallori ve Masson boyama teknikleri en yaygin olarak kullanılmaktadir (Calatzis ve ark. 2003, Lindsay ve ark. 2015, Yenicesu ve ark. 2000). Kesin tan1, farklı bir kesit çapina sahip olan (Pyeritz 2012, De Paepe ve Malfait 2012, De Felice ve ark. 2004, Asherson ve ark. 2006, Lindsay ve ark. 2015) kollajen liflerinin düzensiz yapısını ortaya çıaran bir elektron mikroskobu altında bir deri örneğini inceledikten sonra belirlenebilir.

Hastalık için tedavi yoktur, ancak tutarlı yönetim, etkilenen kedilerin uzun ömürlü yaşaması sağlanabilir (Oderich ve ark. 2005). Hastalık transgenik farelerde deneysel olarak uyarılmıştır (Ong ve ark. 2010). Ehlers-Danlos Sendrom da insanlarda teşhis edilir. Bu durumda 10 türe ayrilır (Busch ve ark. 2014). Tek tek formlar dominant veya resesif bir genle veya kromozom $\mathrm{X}$ ile bağlantılıdır. İnsanlarda, hastalığın nedeninin, kollajen sentezindeki bazı kusurlar ile ilişkili olduğu (örn. Tip VIIc'de procollagen peptidazın aktivitesinde anormallikler) düşünülmektedir (Busch ve ark. 2014). Kedilerde, yakın zamana kadar, iki tip kutanöz asteni belirtilmiştir: baskın ve resesif kalıtım biçimi (Germain 2007, Pepin ve ark. 2000, Stine ve Becton 1997, Calatzis ve ark. 2003) köpeklerde ise, hastalık dominant bir gen ile bağlantılıdır. Ancak bu türlerde ortaya çıkan çekinik tip hakkında bazı öneriler vardır (Calatzis ve ark. 2003). Köpeklerde hastalık en s1k Dachshunds, Boxers, St Bernard köpekleri, Alman çobanları, Springer spaniel, Greyhound, İrlanda setteri ve Poodles (Calatzis ve ark. 2003), kedilerde ise Himalaya (Beighton ve ark. 1998, Pepin ve ark. 2000, Calatzis ve ark. 2003) veya domestik kisa tüylülerde (Germain 2007, Stine ve Becton 1997, Calatzis ve ark. 2003) görülebilmektedir. Bazı yazarlar, kedilerin uzun tüylü irklarının da bu cilt durumuna yatkın olduğunu iddia etmektedir (Germain 2007). Bu iki irkın hiçbirinde cinsiyet eğilimi bulunmamaktadır (Germain 2007). Hastalık klinik bulgulara ve yardımc1 testlere dayanarak teşhis edilir. Klinik muayenede cilt uzayabilirlik indeksi hesaplamasını içermesi çok önemlidir. Bu parametrenin ortalama değerleri köpeklerde $\%$ $14.5^{\prime}$ in üzerinde, kedilerde $\%$ 19'un üzerinde ve tavşanlarda\% 19.2' dir (Pyeritz 2012, De Felice ve ark. 2004, Bergqvist ve ark. 2013, Asherson ve ark. 2006, Calatzis ve ark. 2003).

$\mathrm{Bu}$ olgu serisinde farklı yaş ( $\mathrm{n}=4$ kedi; $1-3$ yaşlı ile $\mathrm{n}=6$ köpek 1-5 yaşli), her 2 cinsiyetten kedi (2 erkek, 2 dişi) ve köpeklerde (4 erkek, 2 dişi) kutanöz asteni (EDS) ile serum $25(\mathrm{OH})$ D3 seviyeleri arasındaki ilişki sunulmaktadır. Çalışmamızda yer alan olgulara ait sonuçlar aşağıda tabloda sunulmuştur.

Tablo 1. Olgulara ait serum vitamin D sonuçları.

Table 1. Serum Vitamin D levels of cases.

\section{EDS Şüpheli Hastalarda Vit D Düzeyleri}

Yüksek

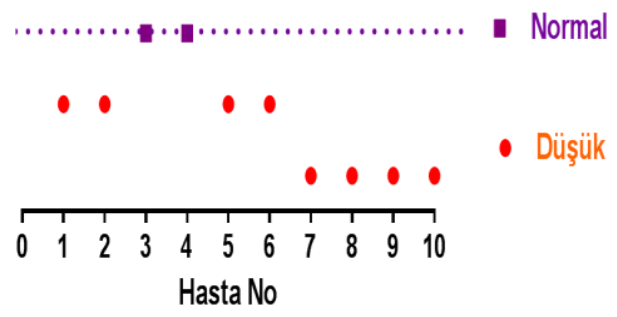

*Olgu no: 1-4 kediler, 5-10 köpekler olarak yer almıştır. 

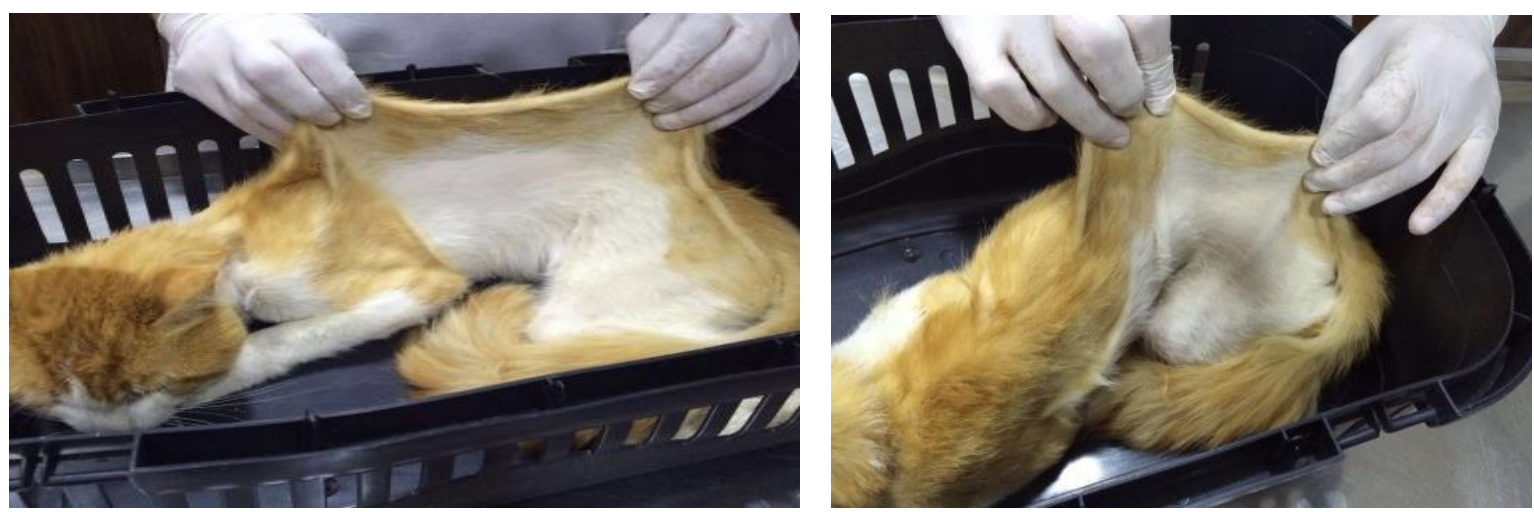

Şekil 1. Olgu 1, 1 yaşlı erkek kedi. Derideki frajilite ve ektensiyon belirgin (Gaziemir Veteriner Kliniği, Veteriner Hekim Kemal Şimşek ile konsülte ve tedavi edilen olgu).

Figure 1. Case 1, a 1-years-old male cat. Explicit fragility and extensibility of skin (treated case was consulted with Veterinarian Kemal Simsek in Gaziemir Veterinary Clinic)
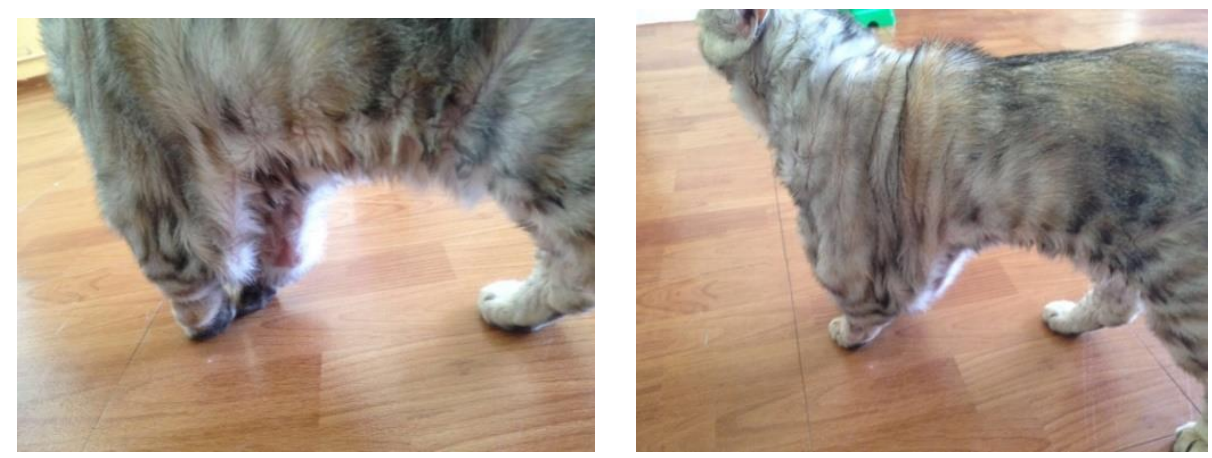

Şekil 2. Olgu 2, 2 yaşlı kedi. Deride sarkma, ekstensiyon dikkat çekici. Vetform Veteriner Kliniği, İstanbul'da Veteriner Hekim Gözde Çetin Kasap ile konsülte edilen olgu.

Figure 2. Case 2, a 2-years-old cat. Remarkable hanging and extension of skin. (case was consulted with Veterinarian Gözde Çetin Kasap in Vetform Veterinary Clinic)

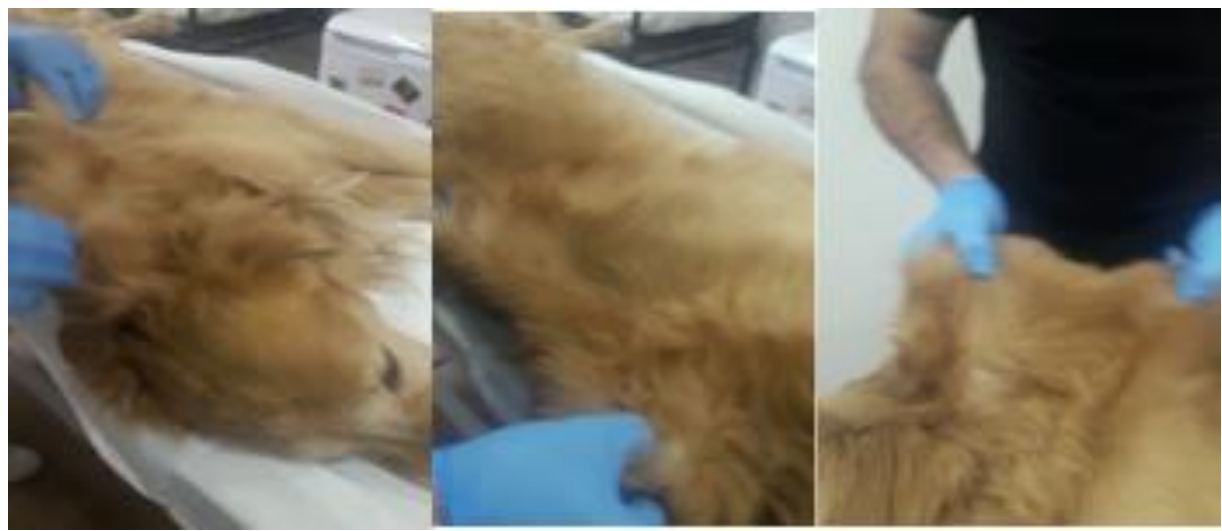

Şekil 3. Olgu 3, 4 yaşlı köpek. Deride ekstensiyon ve fleksibilite artışı. Vetform Veteriner Kliniği, İstanbul'da Veteriner Hekim Gözde Çetin Kasap ile konsülte edilen olgu.

Figure 3. Case 3, 4-years-old dog. Extesion of skin and increased flexibility. (case was consulted with Veterinarian Gözde Çetin Kasap in Vetform Veterinary Clinic) 
Ehlers-Danlos sendromu, kolajen sentezi ve metabolizmasındaki anormalliklerden kaynaklanan ve bağ dokusu bozukluklarından oluşan nadir görülen bir hastalıktır. Hastalık özellikle eklem hipermotilitesi, yaralanma ve artrite yatkınlık, deri ve vasküler problemleri (kolay morarma, kanama, varisli damarlar ve zayıf doku iyileşmesi) kardiyak mitral kapak prolapslar1, iskelet ve kas problemleri (miyopati, miyalji, spinal skolioz, osteoporoz) ve peridontitlere sebep olabilen Ehlers-Danlos sendromunun klasik tipleri (Tip I-III) şeklinde karşımıza çıkmaktadır. Hastalık için günümüzde herhangi bir sağaltım mevcut değildir. Söz konusu hastalıkta ilişkili güncel yaklaşımların; (i) tek başına kusurlu genlerden kaynaklandı̆̆1 düşünüldüğünde hastalığın patogenezinde beslenmenin önemine yönelik olarak bilimsel kanıtların artırılmasının, (ii) Ehlers-Danlos sendromu ile ilişkili semptomların çoğunun aynı zamanda beslenme eksikliklerinde de görülen karakteristik bulgular olduğunun, (iii) normal doku fonksiyonlarının sağlanmasında besin takviyeleri ile oluşturulan uygun kombinasyonların vücut ile sinerjistik etki göstermesi gibi temellere dayanmaktadır. $\mathrm{Bu}$ nedenle, Ehlers-Danlos sendromu ile ilişkili semptomlarin, kalsiyum, karnitin, koenzim Q, glukozamin, magnezyum, metil sülfonil metan, pnoginojen içeren spesifik (ve potansiyel olarak sinerjistik) bir besin takviyesi kombinasyonu kullanılarak başarılı bir şekilde ortadan kaldırılabileceğini varsayılmaktadır (Bergqvist ve ark. 2013). Bununla birlikte silika, $C$ vitamini ve $K$ vitamini, gibi ajanların belirtilen semptomlara karşı etkili olduğu kanıtlanmış durumdadır. Tüm bunlara karşın bu makalenin yazarları nezdinde yapilan literatür taramalarında vitamin d sviyelerinin gerek kedi gerekse köpeklerde incelenmediği saptanmıştır.

Tıp Hekimliği alanında gerçekleştirilen bir çalışmada vasküler tipte EDS bulunan 22 kişinin yarısından fazlasında d vitamini yetersizliği tespit edilmiş, gerekçe olarak vasküler damar bütünlüğünün bozulması gösterilmiştir (Busch ve ark. 2016). Bu makaleye konu olduğu üzere özel ilgi alanımıza girecek şekilde EDS’lu kedi ve köpeklerde (toplamda 8/10) belirlenen düşük vitamin d seviyeleri, bilgimiz ve literatür taramalarımız dahilinde daha önceden tespit edilmemiștir. Vitamin d teşhisinin çok pahalı olmaması, kolekalsiferol yada benzeri bir başka preparat ile oral takviyenin mümkün ve güvenilir (yan etkiye maruz birakmaksızın) gibi tüm öne sürülebilecek gerekçelerden ötürü EDS’lu kedi ve köpeklerde diğer bazı nutriyonel eksikliklerin yanı sıra vitamin d eksikliğinin de göz önünde bulundurulması gerektiği söylenebilinir. Tıp hekimliği alanına benzer şekilde vasküler tipte EDS olgularda oral d vitamini takviyesinin yararlılığ1 antiinflamatuvar ve rejeneratif [kronik düşük dereceli inflamasyona karş1] etkilerinden kaynaklanabilir (Moriestte ve ark. 2014, Wong ve ark. 2014).

\section{KAYNAKLAR}

Pyeritz RE. Ehlers-Danlos syndrome. N Engl J Med. 2000; 342(10):730-2.

De Paepe A, Malfait F. The Ehlers-Danlos syndrome, a disorder with many faces. Clin Genet. 2012; 82(1):1-11.

Beighton P, De Paepe A, Steinmann B, Tsipouras P, Wenstrup RJ. Ehlers-Danlos syndromes: revised nosology, Villefranche, 1997. Ehlers-Danlos National Foundation (USA) and Ehlers-Danlos Support Group (UK). Am J Med Genet. 1998; 77(1):31-7.

Beighton P, de Paepe A, Danks D, Finidori G, Gedde-Dahl T, Goodman R, Hall JG, Hollister DW, Horton W, McKusick VA, et al. International nosology of heritable disorders of connective tissue, Berlin, 1986. Am J Med Genet.1988; 29(3):581-94.

Germain DP. Ehlers-Danlos syndrome type IV. Orphanet J Rare Dis. 2007; 2:32.

De Felice C, Bianciardi G, Dileo L, Latini G, Parrini S. Abnormal oral vascular network geometric complexity in Ehlers-Danlos syndrome. Oral Surg Oral Med Oral Pathol Oral Radiol Endod. 2004; 98(4):429-34.

Lum YW, Brooke BS, Black 3rd JH. Contemporary management of vascular Ehlers-Danlos syndrome. Curr Opin Cardiol. 2011; 26(6):494-501.

Oderich GS, Panneton JM, Bower TC, Lindor NM, Cherry KJ, Noel AA, Kalra M, Sullivan T, Gloviczki P. The spectrum, management and clinical outcome of EhlersDanlos syndrome type IV: a 30-year experience. J Vasc Surg. 2005; 42(1):98-106.

Pepin M, Schwarze U, Superti-Furga A, Byers PH. Clinical and genetic features of EhlersDanlos syndrome type IV, the vascular type. N Engl J Med. 2000; 342(10):673-80.

Bergqvist D, Bjorck M, Wanhainen A. Treatment of vascular Ehlers-Danlos syndrome: a systematic review. Ann Surg. 2013; 258(2):257-61.

Busch A, Suellner J, Anger F, Meir M, Kickuth $\mathbf{R}$, Lorenz U, Wildenauer R. Critical care of kyphoscoliotic type Ehlers-Danlos syndrome with recurrent vascular emergencies. VASA Zeitschrift fur Gefasskrankheiten. 2014; 43(3):216-21.

Horowitz MB, Purdy PD, Valentine RJ, Morrill K. Remote vascular catastrophes after 
neurovascular interventional therapy for type 4 Ehlers-Danlos Syndrome. AJNR Am J Neuroradiol. 2000; 21(5):974-6.

Malfait F, De Paepe A. Bleeding in the heritable connective tissue disorders: mechanisms, diagnosis and treatment. Blood Rev. 2009; 23(5):191-7.

Asherson RA, Bosman C, Tikly M, Spiro F, Pope FM. Ehlers-Danlos syndrome type IV in a young man. J Rheumatol. 2006; 33(10):2091-6.

Calatzis A, Heesen M, Heesen M, Spannag1 M. [Point-of-care testing of hemostatic alterations in anaesthesia and intensive care]. Anaesthesist. 2003; 52(3):229-37.

Lindsay H, Lee-Kim YJ, Srivaths LV: Perioperative Hemostatic Management in Ehlers-Danlos Syndrome: A Report of 2 Cases and Literature Review. Journal of pediatric hematology/oncology. 2015

Yenicesu I, Uckan D, Soysal A, Buyukasik Y, Gumruk F. Platelet release defect in a child with Ehlers-Danlos syndrome. Pediatr Hematol Oncol. 2000; 17(2):193-4.

Morissette R, Schoenhoff F, Xu Z, Shilane DA, Griswold BF, Chen W, Yang J, Zhu J, Fert-Bober J, Sloper L, et al. Transforming growth factor-beta and inflammation in vascular (type IV) EhlersDanlos syndrome. Circ Cardiovasc Genet. 2014; 7(1):80-8

Wong MS, Leisegang MS, Kruse C, Vogel J, Schurmann C, Dehne N, Weigert A, Herrmann E, Brune B, Shah AM, et al. Vitamin D promotes vascular regeneration. Circulation. 2014; 130(12):976-86.

Busch A, Hoffjan S, Bergmann F, Hartung B, Jung H, Hanel D, Tzschach A, Kadar J, Kodolitsch Y, Christoph-Thomas Germer, Trobisch $\mathrm{H}$, Strasser $\mathrm{E}$ and Wildenauer R. Vascular type Ehlers-Danlos syndrome is associated with platelet dysfunction and low vitamin D serum concentration. Orphanet Journal of Rare Diseases. 2016; 11:111. 